JURNAL MAKSIPRENEUR, Vol. VII, No. 1, Desember 2017, hal. 18-30

\title{
ANALISIS FAKTOR MOTIVASI INTRINSIK DAN MOTIVASI EKSTRINSIK PENGARUHNYA TERHADAP KINERJA KARYAWAN DENGAN KEPUASAN KERJA SEBAGAI MEDIASI
}

\author{
Siti Noor Hidayati \\ Fakultas Ekonomi, Universitas Proklamasi 45, Yogyakarta \\ Antonius Ermiyanto \\ PT Taman Wisata Candi Prambanan, Yogyakarta \\ Korespondensi penulis: datik_ng@yahoo.com
}

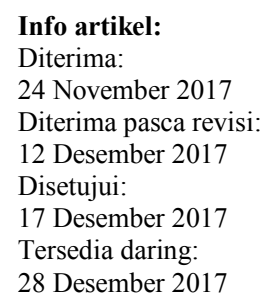

\begin{abstract}
Intrinsic motivation is an employee motivating factor for achievement that comes from within the person, while extrinsic motivation is sourced from outside the person. This research has been conducted to survey on 140 employees of PT Taman Wisata Candi Prambanan consisting of 65 permanent employees and 75 contract employees. The results of this research can be concluded that intrinsic and extrinsic motivation have significant
\end{abstract} effects to employee performance indirectly with job satisfactions mediation. The influence of extrinsic motivation on job satisfaction and subsequently to employee performance is more dominant than intrinsic motivation. The level of intrinsic motivation, extrinsic motivation, job satisfaction, and employee performance of permanent employees, higher than contract employees, and the difference of them is significant.

Keywords: intrinsic motivation, extrinsic motivation, job satisfaction, employee performance.

\section{PENDAHULUAN}

Sumber daya manusia dalam organisasi mempunyai kedudukan yang sangat strategis. Manusia selalu berperan aktif dan dominan dalam setiap kegiatan organisasi karena manusia menjadi perencana, pelaku, dan penentu terwujudnya tujuan organisasi yang tidak akan terwujud tanpa peran aktif karyawan. Karyawan/pekerja/buruh adalah makhluk sosial yang menjadi kekayaan utama bagi setiap organisasi. Pekerja/buruh adalah setiap orang yang bekerja dengan menerima upah atau imbalan dalam bentuk lain (UU RI Nomor 13 Tahun 2003 tentang etenagakerjaan). Karyawan menjadi pelaku yang menunjang tercapainya tujuan organisasi, mempunyai pikiran, perasaan, dan keinginan yang dapat mempengaruhi sikap-sikapnya terhadap pekerjaan. Keberhasilan suatu institusi atau organisasi ditentukan oleh dua faktor utama, yaitu sumber daya manusia atau karyawan atau tenaga kerja dan sarana dan prasarana pendukung atau fasilitas 
kerja. Dari kedua faktor utama tersebut, sumber daya manusia atau karyawan menempati posisi lebih penting daripada sarana dan prasarana pendukung. Secanggih dan selengkap apa pun fasilitas pendukung yang dimiliki suatu organisasi kerja, tanpa adanya sumber daya manusia yang memadai, baik jumlah (kuantitas) maupun kemampuannya (kualitas), niscaya organisasi tersebut tidak dapat berhasil mewujudkan visi, misi, dan tujuan organisasinya (Notoatmodjo, 2014).

Kualitas sumber daya manusia atau karyawan diukur dari kinerja (performance) atau produktivitas karyawan. Kinerja seorang karyawan dapat diukur dari hasil kerja, hasil tugas, atau hasil kegiatan dalam kurun waktu tertentu (Notoatmodjo, 2014). Mangkunegara (2010) mendefinisikan kinerja sebagai hasil kerja secara kualitas dan kuantitas yang dicapai oleh seorang pegawai dalam melaksanakan tugasnya sesuai dengan tanggung jawab yang diberikan kepadanya, sedangkan menurut Prawirosentono (2008), kinerja adalah hasil kerja yang dapat dicapai oleh seseorang atau kelompok dalam suatu organisasi sesuai dengan wewenang dan tanggung jawab masing-masing dalam rangka upaya mencapai tujuan organisasi yang bersangkutan secara legal, tidak melanggar hukum, dan sesuai dengan moral dan etika. Kinerja menurut Hasibuan (2012) adalah suatu hasil kerja yang dicapai seseorang dalam melaksanakan tugas-tugasnya atas kecakapan, usaha, dan kesempatan.

Berdasarkan paparan tersebut di atas, kinerja adalah suatu hasil yang dicapai seseorang dalam melaksanakan tugas-tugas yang didasarkan atas kecakapan, pengalaman, dan kesungguhan, serta waktu menurut standar dan kriteria yang telah ditetapkan sebelumnya. Manajemen kinerja merupakan kebutuhan mutlak bagi organisasi untuk mencapai tujuannya (Wibowo, 2011). Ada banyak faktor yang mempengaruhi prestasi kerja atau kinerja karyawan. Karyawan bekerja dengan produktif atau tidak akan tergantung pada motivasi, kepuasan kerja, tingkat stres, kondisi fisik pekerjaan, sistem kompensasi, disain pekerjaan, dan aspek-aspek ekonomis dan teknis serta keperilakuan lainnya. Pemahaman terhadap faktor-faktor yang mempengaruhi produktivitas tersebut sangat penting karena fungsi personalia dapat memilih faktor-faktor peningkatan produktivitas yang sesuai dengan situasi tertentu (Handoko, 2014).

Motivasi merupakan daya pendorong yang mengakibatkan seorang anggota organisasi mau dan rela mengerahkan kemampuan dalam bentuk keahlian atau ketrampilan, tenaga, dan waktunya untuk menyelenggarakan berbagai kegiatan yang menjadi tanggung jawabnya dan menunaikan kewajibannya dalam rangka pencapaian tujuan dan berbagai sasaran organisasi yang ditentukan. Motivasi merupakan penggerak, alasan-alasan, atau dorongan dalam diri manusia yang menyebabkan manusia melakukan suatu tindakan atau bertingkah laku (Siagian, 2014). Menurut Notoatmodjo (2014), teori motivasi dua faktor Herzberg (Herzberg's Two Factors Motivation Theory) menyatakan bahwa faktor-faktor penyebab kepuasan (satisfier) yang disebut juga faktor motivasional merupakan fakor pendorong seseorang untuk berprestasi yang bersumber dari dalam diri orang tersebut (kondisi intrinsik), sedangkan faktor penyebab ketidakpuasan (dissatisfier) yang disebut juga faktor higiene menyangkut kebutuhan akan pemeliharaan atau maintenance factor merupakan fakor pendorong seseorang untuk berprestasi yang bersumber dari luar diri orang tersebut, terutama dari organisasi tempat dia bekerja (kondisi ekstrinsik). 
Karyawan yang terdorong secara intrinsik akan menyenangi pekerjaan yang memungkinkannya menggunakan kreaktivitas dan inovasinya, bekerja dengan tingkat otonomi yang tinggi, dan tidak perlu diawasi dengan ketat. Sebaliknya, mereka yang lebih terdorong oleh faktor-faktor ekstrinsik cenderung melihat kepada apa yang diberikan oleh organisasi kepada mereka dan kinerjanya diarahkan kepada perolehan hal-hal yang diinginkannya dari organisasi (Sondang, 2002). Faktor motivasional ini mencakup: (1) Prestasi (Achievement), (2) Penghargaan (Recognition), (3) Tanggung jawab (Responsibility), (4) Kesempatan untuk maju (Possibility of growth), (5) Pekerjaan itu sendiri (Work), dan (6) Pertumbuhan dan perkembangan (Growth). Faktor penyebab ketidakpuasan (dissatisfier) atau faktor higiene yang meliputi: (1) Kondisi kerja fisik (physical environment), (2) Hubungan interpersonal (interpersonal relationship), (3) Kebijakan dan administrasi perusahaan (company and administration policy), (4) Pengawasan (supervision), (5) Gaji (salary), dan (6) Keamanan kerja (job security).

Kepuasan kerja (job satisfaction) merupakan keadaan emosional para karyawan dalam memandang pekerjaan yang dilakukan, baik sebagai bentuk yang menyenangkan maupun tidak menyenangkan. Dengan kata lain, kepuasan kerja mencerminkan perasaan seseorang terhadap pekerjaannya (Handoko, 2014). Kepuasan kerja mempunyai arti penting bagi karyawan maupun perusahaan, terutama karena menciptakan keadaan positif di dalam kepuasan kerja tidak akan pernah mencapai kematangan psikologis dan pada gilirannya akan menjadi frustasi. Karyawan seperti ini akan sering melamun, mempunyai semangat kerja yang rendah, cepat lelah dan bosan, emosi tidak stabil, sering absen, dan melakukan kesibukan yang tidak ada hubungannya dengan pekerjaan yang harus dilakukannya. Sebaliknya, karyawan yang mendapatkan kepuasan kerja, biasanya mempunyai catatan kehadiran dan perputaran yang lebih baik, kurang aktif dalam kegiatan serikat karyawan, dan kadang-kadang berprestasi kerja lebih baik daripada karyawan yang tidak memperoleh kepuasan kerja. Kondisi kepuasan atau ketidakpuasan kerja tersebut, selanjutnya menjadi umpan balik yang akan mempengaruhi prestasi kerja di waktu yang akan datang. Jadi, hubungan antara kepuaan kerja dan prestasi kerja menjadi suatu sistem yang berlanjut (Handoko, 2014). Hasil penelitian Juniantara dan Riana (2015) menunjukkan bahwa kepuasan kerja berpengaruh positif dan signifikan terhadap kinerja karyawan. Indikator kepuasan kerja mencakup: 1) pekerjaan, 2) upah atau gaji, 3) pengawasan kerja, 4) kesempatan promosi, dan 5) rekan kerja.

Taman Wisata Candi Prambanan yang berlokasi di Prambanan, Kabupaten Klaten, Jawa Tengah merupakan salah satu unit usaha dan bernaung di bawah Perusahaan Perseroan (Persero) PT Taman Wisata Candi Borobudur, Prambanan, dan Ratu Boko. Pada tahun 2016, telah dilakukan evaluasi atas strategi perusahaan melalui penilaian kinerja, yaitu menggunakan DP4 (Daftar Penilaian Penerapan Prestasi Kerja Pegawai), bagi pegawai organik (pegawai tetap) dan tenaga koperasi. Indikator-indikator kinerja dalam DP4 meliputi: 1) Loyalitas, yang meliputi kesetiaan pada negara, pengabdian pada perusahaan, dan kedisiplinan. 2) Prestasi kerja, yang meliputi kesungguhan kerja, cara kerja, tempo kerja, dan tanggap terhadap tugas pekerjaan (responsiveness). 3) Kemampuan/potensi, yang meliputi daya pikir/inteligensi, inisiatif/prakarsa, kepemimpinan, dan pertanggungjawaban administrasi. 4) Kepribadian, yang meliputi kejujuran, rasa tang- 
gung jawab, keinginan untuk maju, penguasaan emosi, dan penampilan diri. Namun, perusahaan masih menghadapi beberapa kendala. Permasalahan yang dihadapi pada Unit Prambanan, misalnya adalah perlunya visitor manajemen, sedangkan pada Departemen Sumber Daya Manusia pada umumnya adalah penilaian Key Perfomance Indicator (KPI) individu pegawai belum dilaksanakan. Untuk menyikapi hal tersebut, maka strategi perusahaan yang dilakukan salah satunya adalah dengan menciptakan SDM unggul yang kompeten, produktif, dan memiliki kepuasan tinggi dengan strategi penerapan manajemen SDM berbasis kinerja dan optimalisasi tenaga non-organik (pegawai tidak tetap/kontrak) (PT Taman Wisata Candi Borobudur, Prambanan, dan Ratu Boko, 2017).

Hal-hal tersebut merupakan bagian dari fungsi personalia. Fungsi personalia mempunyai pengaruh langsung dan tidak langsung pada kepuasan kerja karyawan. Fungsi personalia dapat membuat kontak langsung dengan para penyelia dan karyawan dengan berbagai cara untuk mempengaruhi karyawan. Di samping itu, berbagai kebijakan dan kegiatan personalia mempunyai dampak pada iklim organisasi. Iklim organisasional ini memberikan suatu lingkungan kerja yang menyenangkan atau tidak menyenangkan bagi orang-orang di dalam organisasi yang selanjutnya akan mempengaruhi kepuasan kerja (Handoko, 2014). Berdasarkan uraian di atas, maka penelitian ini akan mengkaji faktor motivasi intrinsik dan ekstrinsik dengan melihat pengaruhnya terhadap kinerja karyawan dan kepuasan kerja sebagai mediasi. Penelitian ini diharapkan dapat memberikan informasi, masukan, dan gambaran tentang motivasi kerja karyawan, pengaruhnya terhadap kepuasan kerja dan kinerja karyawan. Hal ini sangat penting dalam kaitannya dengan pengambilan keputusan tentang berbagai aspek manajemen sumber daya manusia.

Dengan demikian, permasalahan dalam penelitian ini adalah bagaimana tingkat motivasi intrinsik, motivasi ekstrinsik, kepuasan kerja, dan kinerja karyawan? Apakah motivasi intrinsik dan motivasi ekstrinsik berpengaruh secara tidak langsung terhadap kinerja karyawan Taman Wisata Candi Prambanan dengan kepuasan kerja karyawan sebagai mediasi? Variabel motivasi mana yang pengaruhnya terhadap kinerja karyawan lebih dominan? Apakah ada perbedaan tingkat motivasi intrinsik, motivasi ekstrinsik, kepuasan kerja, dan kinerja karyawan antara karyawan organik (karyawan tetap) dan karyawan kontrak (karyawan tidak tetap). Tujuan yang ingin diraih dengan penelitian ini adalah untuk menganalisis:

1. Karakteristik responden (karyawan) Taman Wisata Candi Prambanan yang meliputi jenis kelamin, usia, pendidikan, dan masa kerja.

2. Tingkat motivasi intrinsik, motivasi ekstrinsik, kepuasan kerja, dan kinerja karyawan Taman Wisata Candi Prambanan.

3. Pengaruh motivasi intrinsik dan motivasi ekstrinsik terhadap kinerja karyawan Taman Wisata Candi Prambanan dengan mediasi kepuasan kerja karyawan.

4. Variabel motivasi yang memiliki pengaruh dominan terhadap kinerja karyawan.

5. Perbedaan tingkat motivasi intrinsik, motivasi ekstrinsik, kepuasan kerja, dan kinerja karyawan Taman Wisata Candi Prambanan antara karyawan organik (karyawan tetap) dan karyawan kontrak (karyawan tidak tetap). 
Berdasar uraian di depan dapat dijelaskan kerangka pikir dalam penelitan ini sebagai berikut: Motivasi merupakan penggerak, alasan-alasan, atau dorongan dalam diri manusia yang menyebabkan manusia melakukan suatu tindakan atau bertingkah laku (Siagian, 2014). Teori motivasi Dua Faktor Herzberg menurut Notoatmodjo (2009) menyatakan bahwa motivasi terdiri dari faktor-faktor penyebab kepuasan (satisfier) dan faktor penyebab ketidakpuasan (dissatisfier). Faktor-faktor penyebab kepuasan yang disebut juga faktor motivasional merupakan fakor pendorong seseorang untuk berprestasi yang bersumber dari dalam diri orang tersebut (kondisi intrinsik). Faktor motivasional ini mencakup prestasi, penghargaan tanggungjawab, kesempatan untuk maju, pekerjaan itu sendiri, serta pertumbuhan dan perkembangan. Faktor-faktor penyebab ketidakpuasan yang disebut juga faktor higiene mencakup kebutuhan akan pemeliharaan merupakan fakor pendorong seseorang untuk berprestasi yang bersumber dari luar diri orang tersebut (kondisi ekstrinsik) Faktor higiene meliputi kondisi kerja fisik, hubungan interpersonal, kebijakan dan administrasi perusahaan, pengawasan, gaji, dan keamanan kerja.

Kepuasan kerja (job satisfaction) merupakan keadaan emosional para karyawan dalam memandang pekerjaan yang dilakukan baik sebagai bentuk yang menyenangkan maupun tidak menyenangkan, dengan kata lain, kepuasan kerja mencerminkan perasaan seseorang terhadap pekerjaannya (Handoko, 2014). Indikator kepuasan kerja mencakup: pekerjaan, upah atau gaji, pengawasan kerja, kesempatan promosi dan rekan kerja. Kepuasan kerja akan berpengaruh berpengaruh terhadap kinerja karyawan (Riana, 2015).

Kinerja adalah suatu hasil yang dicapai seseorang dalam melaksanakan tugas-tugas yang didasarkan atas kecakapan, pengalaman dan kesungguhan serta waktu menurut standar dan kriteria yang telah ditetapkan sebelumnya. Ukuran kinerja menggunakan Daftar Penilaian Pelaksanaan Pekerjaan (DP4). Indikatorindikator DP4 meliputi: loyalitas, prestasi kerja, kemampuan/potensi, dan kepribadian. Dengan deimikian, dapat dikatakan bahwa motivasi intrinsik dan ekstrinsik berpengaruh terhadap kinerja karyawan dengan mediasi kepuasan kerja karyawan. Rerangka pikir penelitian tersebut dapat digambarkan sebagai berikut:

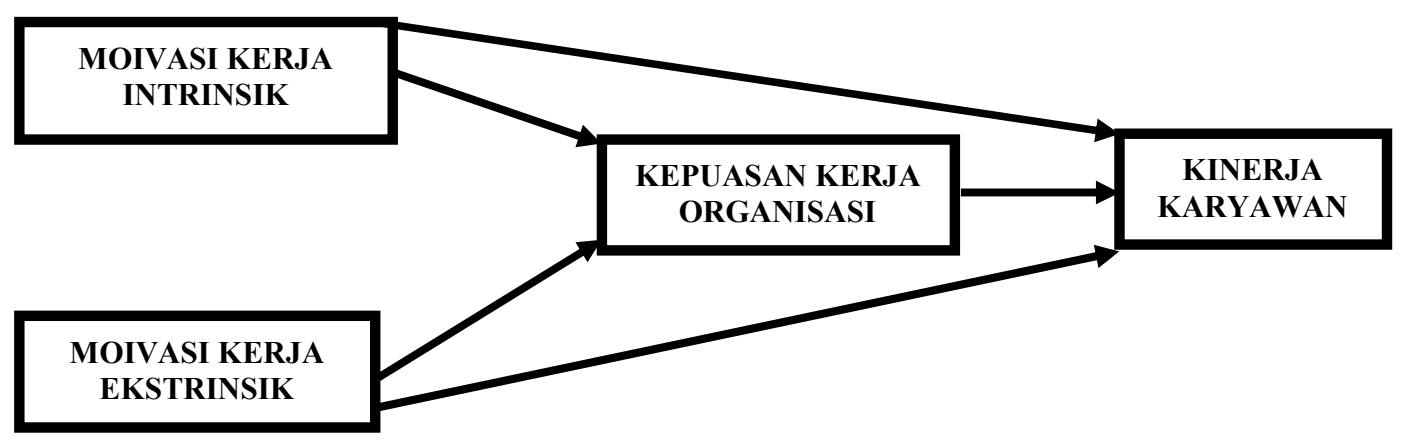

Gambar 1. Rerangka Pikir Penelitian

Berkenaan dengan rerangka pikir penelitian tersebut, maka hipotesis yang diajukan dalam penelitian ini adalah:

1. Ada pengaruh motivasi kerja intrinsik dan ekstrinsik terhadap kepuasan kerja karyawan Taman Wisata Candi Prambanan. 
2. Ada pengaruh motivasi kerja intrinsik dan ekstrinsik terhadap kinerja karyawan Taman Wisata Candi Prambanan.

3. Ada pengaruh motivasi kerja intrinsik, ekstrinsik, dan kepuasan kerja terhadap kinerja karyawan Taman Wisata Candi Prambanan.

4. Ada perbedaan tingkat motivasi kerja intrinsik, ekstrinsik, kepuasan kerja karyawan, dan kinerja karyawan Taman Wisata Candi Prambanan antara karyawan organik (karyawan tetap) dan karyawan kontrak (karyawan tidak tetap).

\section{METODE PENELITIAN}

Penelitian ini dilakukan di Taman Wisata Candi Prambanan. Populasi dalam penelitian ini adalah semua karyawan organik (karyawan tetap) yang berjumlah 65 orang dan karyawan kontrak (karyawan tidak tetap) yang berjumlah 299 orang. Responden dalam penelitian sebanyak 140 orang yang terdiri atas semua populasi karyawan tetap 65 orang dan 75 orang sampel dari karyawan kontrak. Semua populasi karyawan tetap dijadikan responden disebut metode sensus, sedangkan pengambilan sampel karyawan kontrak dengan random sampling (Sugiyono, 2013).

Data yang diperlukan dalam penelitian ini adalah data primer dari responden dan data sekunder dari buku-buku, majalah, koran, maupun data instansi yang ada kaitannya dengan penelitian. Metode pengumpulan data primer menggunakan "Metode Angket," sedangkan metode pengukurannya menggunakan skala Likert, yaitu skala yang digunakan untuk mengukur sikap, pendapat, persepsi dari seseorang tentang fenomena sosial (Sugiyono, 2013). Jawaban dari setiap butir pernyataan disediakan lima alternatif jawaban dan penilaian untuk masing-masing alternatif jawaban diberi bobot (skor): (a) Sangat Tidak Setuju (STS) skor 1, (b) Tidak Setuju (TS) skor 2, (c) Netral (N) skor 3, (d) Setuju (S) skor 4 dan (e) Sangat Setuju (SS) skor 5. Untuk variabel kinerja, penilaian diberikan oleh pimpinan.

Indikator motivasi intrinsik mencakup prestasi, penghargaan, tanggung jawab, kesempatan untuk maju, pekerjaan itu sendiri, serta pertumbuhan dan perkembangan. Indikator motivasi ekstrinsik mencakup kondisi kerja fisik, hubungan interpersonal, kebijakan dan administrasi perusahaan, pengawasan, gaji, dan keamanan kerja. Indikator kepuasan kerja mencakup pekerjaan, upah atau gaji, pengawasan kerja, kesempatan promosi, dan rekan kerja. Indikator-indikator kinerja dalam DP4 mencakup loyalitas, prestasi kerja, kemampuan/potensi, dan kepribadian,

Uji validitas dan reliabilitas instrumen penelitian ini terhadap semua angket (pernyataan) dari variabel motivasi intrinsik, motivasi ekstrinsik, dan kepuasan kerja telah dilakukan dengan sampel 30 orang karyawan. Uji validitas dengan menghitung korelasi Pearson Product Moment (ryx). Hasil perhitungan semua butir pernyataan pada masing-masing variabel diperoleh nilai ryx-hitung lebih besar daripada r-hitung $(0,361)$, sehingga semua butir dinyatakan valid. Uji reliabilitas dengan menghitung alpha Cronbach dengan hasil nilai alpha ketiga variabel tersebut semuanya di atas 0,6 , sehingga semua variabel dinyatakan reliable.

Metode analisis data yang digunakan dalam penelitian ini adalah analisis kualitatif dan kuantitatif sebagai berikut: 
1. Untuk menganalisis karakteristik responden (karyawan) digunakan analisis kualitatif, yaitu analisis yang hanya menggunakan paparan sederhana, baik menggunakan jumlah data maupun persentase dengan membuat distribusi frekuensi (Arikunto, 2013).

2. Untuk menganalisis tanggapan responden (karyawan) terhadap masing-masing variabel motivasi intrinsik, motivasi ekstrinsik, dan kepuasan kerja, serta penilaian kinerja karyawan digunakan distribusi frekuensi dan rata-rata hitung (Mean). Kriteria penilaian motivasi intrinsik, motivasi ekstrinsik, dan kepuasan kerja terdiri atas lima kriteria, yaitu sangat rendah $(1,0-1,7)$, rendah $(1,8-2,5)$, cukup $(2,6-3,3)$, tinggi $(3,4-4,1)$, dan sangat tinggi $(4,2-5,0)$, sedangkan kriteria untuk penilaian kinerja karyawan, yaitu sangat rendah (60-67), rendah (68-75), cukup (76-83), tinggi (84-91), dan sangat tinggi (92-100).

3. Untuk menganalisis pengaruh motivasi intrinsik $\left(\mathrm{X}_{1}\right)$ dan motivasi ekstrinsik $\left(\mathrm{X}_{2}\right)$ terhadap kinerja karyawan $(\mathrm{Z})$ secara tidak langsung dengan variabel antara kepuasan kerja (Y) maupun pengaruhnya secara langsung, atau menguji hipotesis 1, 2, dan 3, dengan menggunakan analisis regresi berganda dan analisis jalur (Ghozali, 2008). Model persamaan regresi berganda sebagai berikut:

$$
\begin{aligned}
& Y=\beta_{1} X_{1}+\beta_{2} X_{2}+\varepsilon 1 \\
& Z=\beta_{1} X_{1}+\beta_{2} X_{2}+\beta_{3} Y+\varepsilon 2
\end{aligned}
$$

Model Struktural Analisis Jalur sebagai berikut:

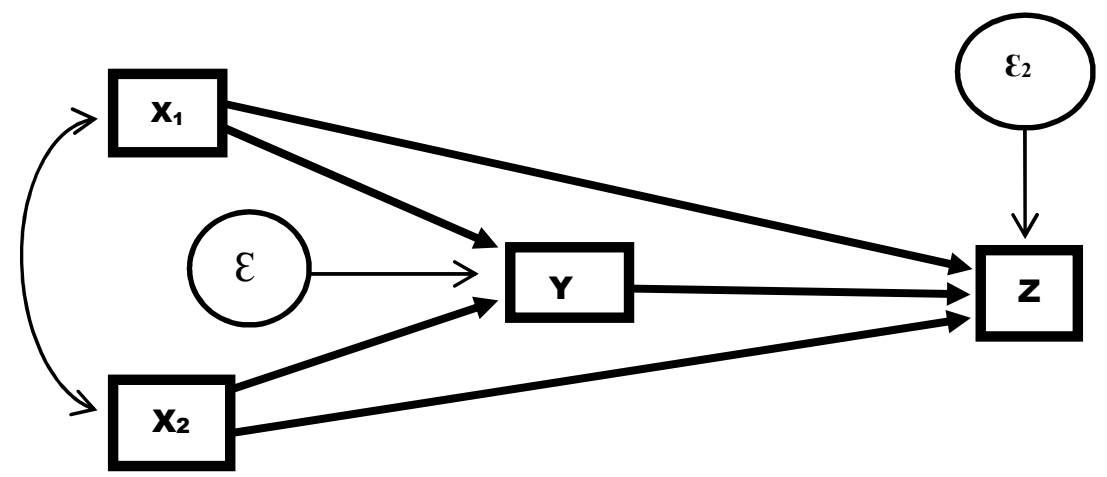

Gambar 2. Model Struktural Analisis Jalur

4. Untuk mengetahui motivasi (X) mana yang pengaruhnya paling dominan terhadap variabel kinerja karyawan $(\mathrm{Z})$ dapat dilihat dari standardized total effect terbesar.

5. Untuk menguji hipotesis 4, menguji perbedaan tingkat motivasi intrinsik, motivasi ekstrinsik, kepuasan kerja karyawan, dan kinerja karyawan antara karyawan organik (karyawan tetap) dan karyawan kontrak (karyawan tidak tetap) menggunakan uji dua rata-rata. 


\section{HASIL PENELITIAN DAN PEMBAHASAN}

Pengumpulan data dengan angket dilakukan terhadap 140 responden karyawan PT Taman Wisata Candi Prambanan untuk dianalisis dan diperoleh hasil sebagai berikut:

1. Responden/karyawan yang berstatus karyawan tetap 65 orang $(46,43 \%)$, berstatus karyawan kontrak 75 orang $(53,57 \%)$, jenis kelamin terbanyak lakilaki yaitu 123 orang $(87,9 \%)$, kelompok usia terbanyak berkisar antara 40-49 tahun yaitu 60 orang (42,9\%), pendidikan terbanyak SMA/SMK yaitu 111 orang $(79,3 \%)$, dan masa kerja antara $1-10$ tahun yaitu 75 orang $(53,6 \%)$.

2. Tanggapan responden terhadap implementasi Motivasi Intrinsik, Motivasi Ekstrinsik, Kepuasan Kerja, dan penilaian pimpinan terhadap Kinerja Karyawan sebagai berikut:

a. Motivasi Intrinsik, dari 140 responden 72 orang $(51,4 \%)$ yang rata-rata nilai skornya tinggi $(\geq 4)$. Nilai rata-rata skor terendah 2,67 dan rata-rata skor tertinggi 4,67. Nilai rata-rata skor dari seluruh responden 3,90 berada pada interval nilai skor $(3,4-4,1)$, maka dapat disimpulkan bahwa Motivasi Intrinsik karyawan Taman Wisata Candi Prambanan termasuk kriteria baik.

b. Motivasi Ekstrinsik, dari 140 responden 98 orang (70\%) yang rata-rata nilai skornya tinggi $(\geq 4)$. Nilai rata-rata skor terendah 3,5 dan rata-rata skor tertinggi 5,0. Nilai rata-rata skor dari seluruh responden 4,09 berada pada interval nilai skor $(3,4-4,1)$, maka dapat disimpulkan bahwa Motivasi Ekstrinsik karyawan Taman Wisata Candi Prambanan termasuk kriteria baik dan bahkan sudah mendekati sangat baik.

c. Kepuasan Kerja, dari 140 responden 120 orang $(85,9 \%)$ yang rata-rata nilai skornya tinggi $(\geq 4)$. Nilai rata-rata skor terendah 2,96 dan rata-rata skor tertinggi 4,44. Nilai rata-rata skor dari seluruh responden 3,76 berada pada interval nilai skor $(3,4-4,1)$, maka dapat disimpulkan bahwa Kepuasan Kerja karyawan Taman Wisata Candi Prambanan termasuk kriteria baik.

d. Kinerja Karyawan, dari 140 responden 89 orang $(63,6 \%)$ yang rata-rata nilai skornya tinggi $(\geq 84)$. Nilai rata-rata skor terendah 76 dan rata-rata skor tertinggi 94 . Nilai rata-rata skor dari seluruh responden 84,25 berada pada interval nilai skor (84-91) maka dapat disimpulkan bahwa Kinerja Karyawan Taman Wisata Candi Prambanan termasuk kriteria baik, meskipun mendekati kriteria cukup.

3. Berdasarkan hasil analisis dengan Program SPSS diperoleh hasil sebagai berikut:

Tabel 1. Standardized Regression Weights

\begin{tabular}{|c|c|c|c|c|}
\hline Regression weights & Estimate & SE & $\mathbf{C R}$ & $\mathbf{P}$ \\
\hline Kepuasan Kerja (YK- - - Motivasi Intrinsik (X1) & 0,130 & 0,829 & 2,134 & 0,035 \\
\hline Kepuasan Kerja (YK- - - - Motivasi Ekstrinsik (X2) & 0,467 & 0,680 & 6,432 & 0,000 \\
\hline \multicolumn{5}{|l|}{$\varepsilon_{1}=0,29$} \\
\hline Kinerja Karyawan $(Z)<--$ Motivasi Intrinsik (X1) & 0,112 & 0,660 & 1,543 & 0,125 \\
\hline Kinerja Karyawan $(\mathrm{Z})<--\cdot$ Motivasi Ekstrinsik (X2) & 0,093 & 0,960 & 1,526 & 0,129 \\
\hline Kinerja Karyawan $(\mathrm{Z})<---\operatorname{Kepuasan} \operatorname{Kerja}(\mathrm{Y})$ & 0,505 & 1,064 & 8,305 & 0,000 \\
\hline$\varepsilon_{2}=3,64$ & & & & \\
\hline
\end{tabular}


Persamaan Regresi dengan standardized coefficients:

$$
\begin{aligned}
& Y=0,136 X_{1}+0,484 X_{2} \\
& Z=0,116 X_{1}+0,110 X_{2}+0,594 Y
\end{aligned}
$$

Tabel 2. Standardized Direct Effect

\begin{tabular}{cccc}
\hline & $\begin{array}{c}\text { Motivasi } \\
\text { Intrinsik (X) }\end{array}$ & $\begin{array}{c}\text { Motivasi } \\
\text { Ekstrinsik }\left(\mathbf{X}_{\mathbf{2}}\right)\end{array}$ & $\begin{array}{c}\text { Kepuasan Kerja } \\
(\mathbf{Y})\end{array}$ \\
\hline Kepuasan Kerja (Y) & 0,136 & 0,484 & 0,000 \\
\hline Kinerja Karyawan $(\mathrm{Z})$ & 0,116 & 0,110 & 0,594 \\
Sumber: Hasil pengolahan data $(2017)$. & &
\end{tabular}

Tabel 3. Standardized Indirect Effect

\begin{tabular}{cccc}
\hline & $\left.\begin{array}{c}\text { Motivasi } \\
\text { Intrinsik ( }\end{array} \mathbf{X}_{\mathbf{1}}\right)$ & $\begin{array}{c}\text { Motivasi } \\
\text { Ekstrinsik }\left(\mathbf{X}_{\mathbf{2}}\right)\end{array}$ & $\begin{array}{c}\text { Kepuasan Kerja } \\
(\mathbf{Y})\end{array}$ \\
\hline Kepuasan Kerja $(\mathrm{Y})$ & 0,000 & 0,000 & 0,000 \\
\hline Kinerja Karyawan $(\mathrm{Z})$ & 0,081 & 0,287 & 0,000 \\
\hline
\end{tabular}

Sumber: Hasil pengolahan data (2017).

Tabel 4. Standardized Total Effect

\begin{tabular}{cccc}
\hline & $\begin{array}{c}\text { Motivasi } \\
\text { Intrinsik (X) }\end{array}$ & $\begin{array}{c}\text { Motivasi } \\
\text { Ekstrinsik (X) }\end{array}$ & $\begin{array}{c}\text { Kepuasan Kerja } \\
(\mathbf{Y})\end{array}$ \\
\hline Kepuasan Kerja (Y) & 0,136 & 0,484 & 0,000 \\
\hline Kinerja Karyawan $(\mathrm{Z})$ & 0,197 & 0,97 & 0,594 \\
\hline
\end{tabular}

Sumber: Hasil pengolahan data (2017).

\section{Pengujian Hipotesis 1, 2, dan 3:}

Dari Tabel 1, hasil tersebut membuktikan adanya pengaruh positif dan signifikan dari Motivasi Intrinsik (X1) dan Motivasi Ekstrinsik (X2) terhadap Kepuasan Kerja (Y), serta Kepuasan Kerja (Y) terhadap Kinerja Karyawan (Z). Nilai probabilitas semuanya berada di bawah nilai 0,05 . Untuk pengaruh secara langsung dari Motivasi Intrinsik (X1) dan Motivasi Ekstrinsik (X2) terhadap Kinerja Karyawan (Z), pengaruhnya ada, tetapi sangat kecil sehingga secara statistik dikatakan tidak signifikan yaitu dengan nilai probabilitas semuanya di atas nilai 0,05 . Di sisi lain, pengaruh komitmen organisasi $(Y)$ terhadap kinerja pegawai $(\mathrm{Z})$ menunjukkan hasil posistif dan signifikan dengan nilai probabilitas 0,00 . Hal tersebut menggambarkan bahwa pengaruh dari Motivasi Intrinsik (X1) dan Motivasi Ekstrinsik (X2) terhadap Kinerja Karyawan $(Z)$ terbukti pengaruhnya secara tidak langsung melalui variabel Kepuasan Kerja (Y) sebagai mediasi, sedangkan pengaruhnya yang langsung terbukti tidak signifikan. Dengan demikian, Motivasi Intrinsik (X1) dan Motivasi Ekstrinsik (X2) berpengaruh secara signifikan terhadap Kepuasan Kerja (Y). Selain itu, Kepuasan Kerja (Y) berpengaruh secara signifikan terhadap Kinerja Karya-wan (Z). Pengaruh positif menggambarkan bahwa meningkatnya Motivasi Intrinsik (X1) dan Motivasi Ekstrinsik (X2) akan meningkatkan Kepuasan Kerja (Y) dan selanjutnya akan meningkatkan Kinerja Karyawan (Z).

4. Variabel yang dominan. Dari Tabel 4 dapat diketahui bahwa standardized total effect variabel Motivasi Ekstrinsik $\left(\mathrm{X}_{2}\right)=0,397$ lebih besar dibanding Motivasi Intrinsik $(\mathrm{X} 1)=0,197$. Hal tersebut menggambarkan bahwa 
pengaruh Motivasi Ekstrinsik $\left(\mathrm{X}_{2}\right)$ terhadap Kepuasan Kerja (Y) dan Kinerja Karyawan (Z) adalah lebih dominan dibandingkan pengaruh Motivasi Intrinsik (X1). Hal ini menggambarkan bahwa fakor pendorong karyawan untuk berprestasi yang bersumber dari luar diri karyawan tersebut (kondisi ekstrinsik) lebih besar daripada fakor pendorong yang bersumber dari dalam diri orang tersebut (kondisi intrinsik). Karyawan yang lebih terdorong oleh faktor-faktor ekstrinsik cenderung melihat kepada apa yang diberikan oleh organisasi kepada mereka dan kinerjanya diarahkan kepada perolehan hal-hal yang diinginkannya dari organisasi (Siagian, 2004).

5. Hipotesis 4. Untuk menguji hipotesis 4, yaitu menguji perbedaan tingkat motivasi intrinsik, motivasi ekstrinsik, kepuasan kerja, dan kinerja karyawan antara karyawan organik (karyawan tetap) dan karyawan kontrak (karyawan tidak tetap) digunakan uji perbedaan dua rata-rata.

a. Perbedaan Motivasi Intrinsik antara Responden yang berstatus Karyawan Tetap dan Karyawan Kontrak.

Tabel 5. Perbedaan Rata-Rata Motivasi Intrinsik antara Responden yang Berstatus Karyawan Tetap dan Karyawan Kontrak

\begin{tabular}{clccc}
\hline No & Responden & $\begin{array}{c}\text { Rata-rata } \\
\text { Mean }\end{array}$ & p-value \\
& & $\begin{array}{c}\mathbf{( \mathbf { x } )} \\
\text { Difference }\end{array}$ & \\
\hline 1 & Karyawan Tetap & 4,09 & 0,33 & 0,000 \\
\hline
\end{tabular}

Sumber: Hasil pengolahan data (2017).

Tabel 5 menunjukkan bahwa terdapat perbedaan yang signifikan antara rata-rata motivasi kerja pada responden yang berstatus karyawan tetap dan karyawan kontrak $(\mathrm{p}=0,000<0,05)$ dengan perbedaan sebesar 0,33 . Tabel 5 tersebut juga menunjukkan bahwa rata-rata motivasi kerja pada responden yang berstatus karyawan tetap lebih tinggi dibandingkan yang berstatus karyawan kontrak.

b. Perbedaan Motivasi Ekstrinsik antara Responden yang Berstatus Karyawan Tetap dan Karyawan Kontrak.

Tabel 6. Perbedaan Rata-Rata Motivasi Ekstrinsik antara Responden yang Berstatus Karyawan Tetap dan Karyawan Kontrak

\begin{tabular}{clccc}
\hline No & Responden & $\begin{array}{c}\text { Rata-rata } \\
-\end{array}$ & $\begin{array}{c}\text { Mean } \\
\text { Difference }\end{array}$ & p-value \\
\hline 1 & Karyawan Tetap & 4,31 & 0,52 & 0,000 \\
\hline 2 & Karyawan Kontrak & 3,79 & & \\
\hline
\end{tabular}

Sumber: Hasil pengolahan data (2017).

Tabel 6 menunjukkan bahwa terdapat perbedaan yang signifikan rata-rata motivasi kerja pada responden yang berstatus karyawan tetap dan karyawan kontrak $(\mathrm{p}=0,000<0,05)$ dengan perbedaan sebesar 0,52 . Tabel 6 tersebut juga menunjukkan bahwa rata-rata motivasi kerja pada responden yang berstatus karyawan tetap lebih tinggi dibandingkan yang berstatus karyawan kontrak. 
c. Perbedaan Kepuasan Kerja antara Responden yang Berstatus Karyawan tetap dan Karyawan Kontrak.

Tabel 7. Perbedaan Rata-Rata Kepuasan Kerja antara Responden yang Berstatus Karyawan Tetap dan Karyawan Kontrak

\begin{tabular}{ccccc}
\hline No & Responden & $\begin{array}{c}\text { Rata-rata } \\
(\mathbf{x})\end{array}$ & $\begin{array}{c}\text { Mean } \\
\text { Difference }\end{array}$ & p-value \\
\hline 1 & Karyawan Tetap & 3,89 & & 0,24 \\
\hline 2 & Karyawan Kontrak & 3,65 & 0,24 & 0,000 \\
\hline
\end{tabular}

Sumber: Hasil pengolahan data (2017).

Tabel 7 menunjukkan bahwa terdapat perbedaan yang signifikan rata-rata kepuasan kerja pada responden yang berstatus karyawan tetap dan karyawan kontrak $(p=0,000<0,05)$ dengan perbedaan sebesar 0,247 . Tabel 7 tersebut juga menunjukkan bahwa rata-rata kepuasan kerja pada responden yang berstatus karyawan tetap lebih tinggi dibandingkan yang berstatus karyawan kontrak.

d. Perbedaan Kinerja antara Responden yang Berstatus Karyawan Tetap dan Karyawan Kontrak.

Tabel 8. Perbedaan Rata-Rata Kinerja antara Responden yang Berstatus Karyawan Tetap dan Karyawan Kontrak

\begin{tabular}{clccc}
\hline No & Responden & $\begin{array}{c}\text { Rata-rata } \\
(\mathbf{x})\end{array}$ & $\begin{array}{c}\text { Mean } \\
\text { Difference }\end{array}$ & p-value \\
\hline 1 & Karyawan Tetap & 87,09 & \multirow{2}{*}{5,3} & 0,000 \\
\hline 2 & Karyawan Kontrak & 81,79 & & \\
\hline
\end{tabular}

Sumber: Hasil pengolahan data (2017).

Tabel 8 menunjukkan bahwa terdapat perbedaan yang signifikan rata-rata kinerja pada responden yang berstatus karyawan tetap dan karyawan kontrak $(p=0,000<0,05)$ dengan perbedaan sebesar 5,3. Tabel 8 tersebut juga menunjukkan bahwa rata-rata kinerja pada responden yang berstatus karyawan tetap lebih tinggi daripada karyawan kontrak.

\section{KESIMPULAN DAN SARAN}

Dari hasil penelitian dan pembahasan di atas dapat disimpulkan:

1. Karakteristik 140 orang responden/karyawan adalah berstatus karyawan tetap 65 orang $(46,43 \%)$, berstatus karyawan kontrak 75 orang $(53,57 \%)$, jenis kelamin terbanyak laki-laki yaitu 123 orang $(87,9 \%)$, usia terbanyak berkisar antara 40-49 tahun yaitu 60 orang (42,9\%), pendidikan terbanyak SMA/SMK yaitu 111 orang $(79,3 \%)$, dan masa kerja berkisar antara 1-10 tahun yaitu 75 orang $(53,6 \%)$.

2. Tanggapan responden terhadap implementasi Motivasi Intrinsik, Motivasi Ekstrinsik, Kepuasan Kerja, dan penilaian pimpinan terhadap Kinerja Karyawan sebagai berikut:

a. Motivasi Intrinsik. Nilai rata-rata skor dari seluruh responden 3,90, termasuk kriteria baik.

b. Motivasi Ekstrinsik. Nilai rata-rata skor dari seluruh responden 4,09, termasuk kriteria baik dan bahkan sudah mendekati sangat baik. 
c. Kepuasan Kerja. Nilai rata-rata skor dari seluruh responden 3,76, termasuk kriteria baik.

d. Kinerja Karyawan, Nilai rata-rata skor dari seluruh responden 84,25 masih termasuk dalam kriteria baik, meskipun mendekati kriteria cukup.

3. Motivasi Intrinsik (X1) dan Motivasi Ekstrinsik (X2) terbukti signifikan pengaruhnya secara tidak langsung terhadap Kinerja Karyawan (Z) dengan Kepuasan Kerja (Y) sebagai mediasi, sedangkan pengaruh langsung terbukti tidak signifikan. Dengan demikian, dapat dikatakan bahwa Motivasi Intrinsik (X1) dan Motivasi Ekstrinsik berpengaruh secara signifikan terhadap Kepuasan Kerja (Y), dan Kepuasan Kerja (Y) berpengaruh secara signifikan terhadap Kinerja Karyawan (Z). Pengaruh positif menggambarkan bahwa meningkatnya Motivasi Intrinsik (X1) dan Motivasi Ekstrinsik (X2) akan meningkatkan Kepuasan Kerja (Y) dan selanjutnya meningkatkan Kinerja Karyawan (Z).

4. Pengaruh Motivasi Ekstrinsik $\left(\mathrm{X}_{2}\right)$ terhadap Kepuasan Kerja dan Kinerja Karyawan adalah lebih dominan dibandingkan Motivasi Intrinsik (X1). Karyawan cenderung melihat kepada apa yang diberikan oleh organisasi kepada mereka dan kinerjanya diarahkan kepada perolehan hal-hal yang diinginkannya dari organisasi.

5. Ada perbedaan yang signifikan antara karyawan tetap dan karyawan kontrak mencakup semua variabel Motivasi Intrinsik (X1), Motivasi Ekstrinsik (X2), Kepuasan Kerja (Y), dan Kinerja Karyawan (Z) dengan rata-rata skor masingmasing variabel dari karyawan tetap lebih tinggi daripada karyawan kontrak.

Saran yang diajukan berdasarkan pada hasil penelitian ini adalah:

1. Motivasi kerja tidak berpengaruh langsung terhadap kinerja karyawan, tetapi dengan mediasi kepuasan kerja. Dengan demikian, organisasi yang ingin meningkatkan kinerja karyawannya harus lebih memperhatikan kepuasan kerja karyawannya.

2. Motivasi ekstrinsik lebih dominan dibandingkan motivasi intrinsik dalam meningkatkan kepuasan kerja dan kinrerja karyawan, berarti kinerjanya diarahkan kepada perolehan yang dberikan organisasi. Maka, perlu ada pembinaan lebih lanjut agar karyawan dapat meningkatkan motivasi intrinsiknya, sehingga karyawan secara intrinsik akan menyenangi pekerjaan yang memungkinkannya menggunakan kreaktivitas dan inovasinya, bekerja dengan tingkat otonomi yang tinggi, dan tidak perlu diawasi dengan ketat.

3. PT Taman Wisata Candi Prambanan mempekerjakan karyawan kontrak (299 orang) lebih banyak dari karyawan kontrak (65 orang), sehingga penyelesaian pekerjaan sangat tergantung pada dukungan karyawan kontrak. Sementara itu, rata-rata tingkat motivasi intrinsik, motivasi ekstrinsik, kepuasan kerja, dan kinerja karyawan tetap menunjukkan lebih tinggi dengan perbedaan yang signifikan. Untuk itu, peningkatan kinerja organisasi melalui peningkatan kinerja karyawan memerlukan upaya-upaya agar kinerja karyawan, khususnya karyawan kontrak perlu lebih ditingkatkan, sehingga organisasi perlu melakukan penelitian-penilitan lebih lanjut berkaitan dengan hal tersebut. 


\section{DAFTAR REFERENSI}

Arikunto, S. (2013). Prosedur Penelitian Suatu Pendekatan Praktik. Jakarta: PT Rineka Cipta.

Ghozali, I. (2008). Model Persamaan Struktural, Konsep, dan Aplikasi dengan Program AMOS. Semarang: Badan Penerbit Universitas Diponegoro.

Handoko, T.H. (2014). Manajemen Personalia \& Sumberdaya Manusia. Yogyakarta: Badan Penerbit Fakultas Ekonomi UGM.

Hasibuan, M.S.P. (2012). Manajemen Sumber Daya Manusia. Jakarta: PT Bumi Aksara.

Juniantara, I.W. \& Riana, I.G. (2015). Pengaruh Motivasi dan Kepuasan Kerja Terhadap Kinerja Karyawan Koperasi di Denpasar. E-journal Ekonomi dan Bisnis, 4(09). Universitas Udayana.

Mangkunegara, A.P. (2010). Evaluasi Kinerja SDM. Bandung: Refika Aditama.

Notoatmodjo, S. (2014). Pengembangan Sumber Daya Manusia. Jakarta: PT Rineka Cpita.

Prawirosentono, S. (2008). Kebijakan Kinerja Karyawan. Yogyakarta: Badan Penerbit Fakultas Ekonomi UGM.

Republik Indonesia. (2003). Undang-Undang RI Nomor 13 Tahun 2003 Tentang Ketenagakerjaan. Jakarta: Kemensekneg RI.

Siagian, P.S. (2004). Teori Motivasi dan Aplikasinya. Jakarta: PT Bumi Aksara. . (2014). Manajemen Sumber Daya Manusia. Jakarta: PT Bumi Aksara.

Sugiyono, (2013). Metode Penelitian, Kualitatif, Kuantitatif dan R\&D. Bandung: Penerbit Alfabeta.

Wibowo. (2011). Manajemen Kinerja. Jakarta: Rajawali Pers. 